\title{
Evaluation of Heavy Metals Contamination Level (Mercury, Lead, Cadmium) in Fishery Products Exported From Senegal
}

\author{
Abdoulaye DIOUF \\ Direction des Industries de Transformation de la Pêche (DITP), Km 10,5 - Route de \\ Rufisque - BP 50700 - CP 18524. \\ Jean FALL (Corresponding author) \\ Institut Universitaire de Pêche et d'Aquaculture (IUPA), Bâtiment Pédagogique, Rez de \\ Chaussée UCAD II, BP 5005 \\ E-mail: kagoshima77@yahoo.com
}

\begin{abstract}
Abdou Samath DIOUF
Institut Universitaire de Pêche et d'Aquaculture (IUPA), Bâtiment Pédagogique, Rez de Chaussée UCAD II, BP 5005
\end{abstract}

\section{Mame Mor NDOUR}

Direction des Industries de Transformation de la Pêche (DITP), Km 10,5 - Route de Rufisque - BP 50700 - CP 18524

\section{Diegane NDONG}

Direction des Ressources Animales et Halieutiques, Département de l'Agriculture, des Ressources en Eau et de l'Environnement, Commission de l'UEMOA, 380 Av. Pr. Joseph KI-ZERBO, 01 BP 543 Ouagadougou 01-Burkina Faso

Received: October 11, 2018 Accepted: July 10, 2019 Published: August 12, 2019 doi:10.5296/jfs.v8i1.15261 URL: https://doi.org/10.5296/jfs.v8i1.15261 


\title{
Mll Macrothink
}

\begin{abstract}
Domestic, hospital and industrial wastes are major generators of heavy metals. These wastes added to those found in nature pollute the aquatic environment through the discharge. Heavy metals are toxic to living organisms. They accumulate in these beings. Humans get intoxicated by ingesting fish species contaminated by heavy metals. To evaluate the risk of intoxication of humans, it is proposed to determine the mercury, lead and cadmium content of fish and shellfish processed in Senegal. The contamination level of mercury content is determined by the DMA 80. The lead and cadmium content in the species is made by atomic absorption spectrophotometry (AAS). The results obtained show that among the metals measured, lead has the highest content in all species. This is due to its abundance in the waste. Lead is more concentrated in species that live on the bottom. Large species concentrate high levels of mercury due to accumulation and biomagnification. Cadmium is the most concentrated in invertebrates, most of whose consumption consists of plants. The levels of all heavy metals measured in species do not exceed national and international standards. But as metals accumulate, monitoring is needed to limit poisoning.
\end{abstract}

Keywords: Heavy metals, Accumulation, Biomagnification, Intoxication.

\section{Introduction}

Large amounts of pollutants are released daily into the environment. Among them, heavy metals are considered to be serious pollutants in the aquatic environment because of their persistence and their tendency to bioaccumulate in aquatic organisms (Harte et al., 1991, Schuurmann \& Markert, 1998). Several heavy metals are found in the aquatic environment, by human action, by atmospheric transport and as a result of erosion due to rain (Veena et al., 1997). As a result, aquatic animals may be exposed to high concentrations of heavy metals (Kalay \& Canh 2000). Heavy metals can thus affect organisms directly by accumulating in their bodies or, indirectly by transfer through the food chain. Contamination of aquatic ecosystems by heavy metals can be confirmed in water, sediment and organisms (Forstner \& Wittman 1983).

The accumulation of heavy metals in these compartments can result of serious ecological changes. One of the serious causes of their persistence is the biomagnification of these metals in the food chain (Unlu \& Gumgum, 1993). Metals that are transferred through the aquatic environment to fish, humans and other piscivorous animals can have impacts on the environment and human health (Chen et al., 2000). Cadmium (Cd), mercury ( $\mathrm{Hg}$ ) and lead $(\mathrm{Pb})$; are not essential metals; their positive role in cells, to date, is not known (Altindag et al., 2005).

The problems associated with heavy metal contamination were first highlighted in the industrialized countries, because of their larger industrial developments, and especially as a result of accidents due to cadmium pollution in Sweden and mercury in Japan (Minamata disease 1949-1965) (Kurland et al., 1960, Nitta, 1972, Gigon, 1975, Goldberg, 1979, Jobin, 2006). Although the level of industrial activity is relatively lower in most African countries, there is a growing awareness of the need for rational management of aquatic resources, including the need to control the discharge of waste into the environment (Rashed, 2001, Chale, 2002, Okwonko et al., 2005, Assonye et al., 2007). 


\section{Macrothink}

In Senegal, fishing is an essential pillar of the economy because of the importance it plays economically, socially and in food, as attested by the following indicators: $2.3 \%$ of national GDP, $12,5 \%$ of the GDP of the primary sector, $17 \%$ of the active population and more than $75 \%$ of the animal protein needs of the Senegalese population.

Senegal is the second country in West and North Africa behind Morocco to be approved for export of fishery products to the European Union by Decision 96/355 / EEC of 30 May 1996 amended by the Decision 555 of 5 July 2005.

The general objective of the present study was to assess the contamination level of heavy meatls in fish products. The specific objectives are: (1) to indicate the species most exposed to heavy metal contamination; (2) to provide primary data for risk analysis of heavy metals in fishery products and (3) to contribute to the improvement of official control and self-control programs for heavy metals in fish products.

\section{Methodology of the Study}

The study deals with the results of heavy metal analysis carried out on samples taken at the processing and exporting of fishery products.

\subsection{Data Sources}

Table 1. Evolution of exports and landings of fiheries production in Senegal from 2013 to 2017

\begin{tabular}{lllllll}
\hline & 2013 & 2014 & 2015 & 2016 & 2017 & Mean \\
\hline Exportation (E) in tons & 137596.53 & 150908.69 & 188462.93 & 192162.50 & 207035.94 & 175233.32 \\
Landing (L) in tons & 411372 & 382107 & 393225 & 495880 & 510596 & 438636 \\
Ratio (E/L) (\%) & 33.45 & 39.49 & 47.93 & 38.75 & 40.55 & 40.03 \\
\hline
\end{tabular}

Landings of marine and inland fisheries have generally increased over the considered 5 years. The fisheries production was around 438600 tons with a maximum of 510596 tons in 2017. This same trend was observed with exports, which averaged around 175200 tons per year. In 2017, the exportation volume was 200000 tons with an estimated commercial value of 244 billions of CFA. The mean ratio of exported volumes and the landings production was $40 \%$.

The results exploited concern 2581 samples recorded by the office of inspection and control of halieutics products (DIC) in nine (9) years as part of the official analysis. Samples were taken from 74 fish and shellfish processing plants and 92 fishing vessels. The analyzes were conducted at three (03) partner laboratories in the Competent Authority (CA). The Tables 2, 3, 4 and 5 below give the distribution of the analyzed samples by year and by type of contaminant.

\subsection{Heavy Metals Analysis}

$\mathrm{Hg}$ was performed using a direct $\mathrm{Hg}$ analyzer (DMA80, atomic absorption spectrophotometer, Milestone, Wesleyan University, Mid- dletown, CT, USA). The analyzed samples were species of fish and shellfish exported from Senegal. In all cases, three aliquots of each sample were analyzed. Fish samples were prepared by dissection of the edible parts, which were 


\section{MInstitute Macrothink $_{\text {Int }}$}

dried at $80{ }^{\circ} \mathrm{C}$ for $24 \mathrm{~h}$ and homogenized by grinding in a glass mortar. The preparation of the samples was based on the method for mercury speciation proposed by (Ubillús et al., 2000).

An atomic absorption spectrometer (Perkin-Elmer $4110 \mathrm{ZL}$ ) equipped with graphite furnace and As-72 autosampler was used for the determination of $\mathrm{Pb}$ and $\mathrm{Cd}$ according to the method of Szkoda and Zmudzki 2005. Briefly, 2 to $10 \mathrm{~g}$ of sample was weighed in $50 \mathrm{ml}$ of crucible. Samples were completely dry in an oven at $120 \pm 20^{\circ} \mathrm{C}$. The samples were placed in a cold muffle furnace and the oven temperature was increased to $450 \pm 20{ }^{\circ} \mathrm{C}\left(50{ }^{\circ} \mathrm{C} / \mathrm{h}\right)$. The samples from the oven were remove and allowed to cool to room temperature. $1 \mathrm{ml}$ of concentrated nitric acid was added and the ashes put on a hot plate to dry. The samples were return to the muffle furnace and the temperature raised to $450{ }^{\circ} \mathrm{C}$. the sample were keep at this temperature for about 1 hour. The ashes must be carbon-free. The sample were remove from the muffle oven and allow to cool to room temperature. The sample ash was dissolve in 5-10 $\mathrm{ml}$ of $1 \mathrm{~N} \mathrm{HCl}(1 \mathrm{~g}$ of sample in $1 \mathrm{ml}$ of $\mathrm{HCl})$. The solution of the crucible transfer into a clean tube. The final solutions of the samples were diluted in $0.2 \%$ nitric acid. Each batch must include a blank reagent and a control sample containing all reagents in the same volumes. Heavy metals were determined by graphite furnace atomic absorption spectrofotometer (GF AAS). After the atomization steps, the concentrations of lead and cadmium were reported in the computer in $\mu \mathrm{g}$ of metals / $\mathrm{g}$, wet weight of the sample

Table 2. Summary table of the samples analyzed as part of the official control of heavy metals (2008-2016)

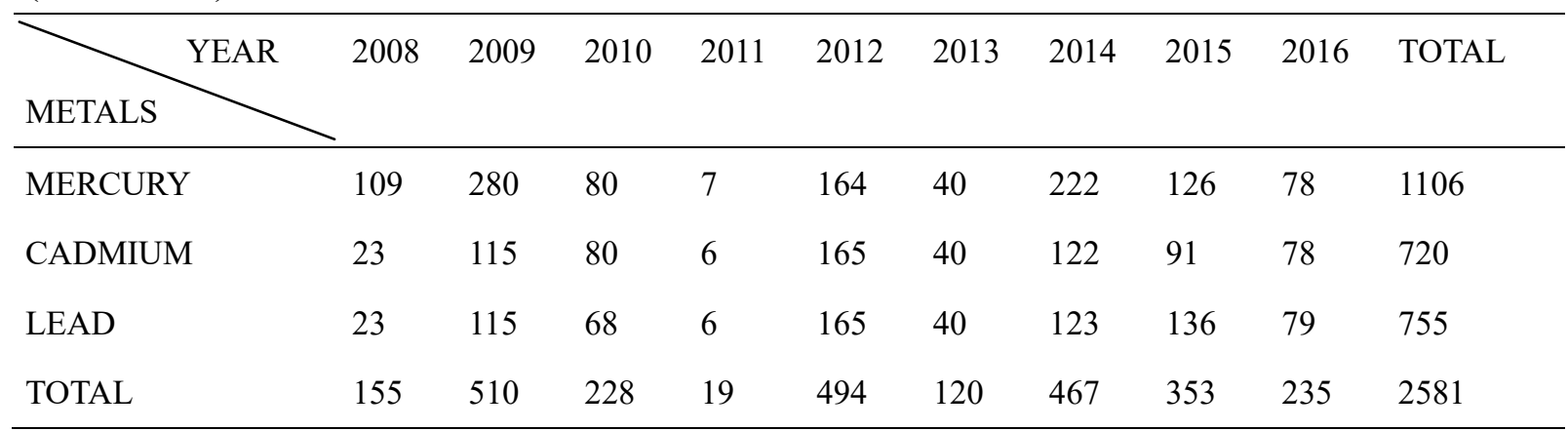

Table 3. Summary table of the samples analyzed as part of the official control of mercury (2008-2016)

\begin{tabular}{cccccccccccc}
\hline YEAR & 2008 & 2009 & 2010 & 2011 & 2012 & 2013 & 2014 & 2015 & 2016 & TOTAL & $\%$ \\
\hline Samples containing mercury & 104 & 276 & 65 & 3 & 98 & 38 & 154 & 48 & 4 & 790 & 71 \\
Samples without Mercury & 5 & 4 & 15 & 4 & 66 & 2 & 68 & 78 & 74 & 316 & 29 \\
TOTAL & 109 & 280 & 80 & 7 & 164 & 40 & 222 & 126 & 78 & 1106 & 100 \\
\hline
\end{tabular}




\section{Macrothink}

Table 4. Summary table of the samples analyzed as part of the official control of cadmium (2008-2016)

\begin{tabular}{llllllllllll}
\hline YEAR & 2008 & 2009 & 2010 & 2011 & 2012 & 2013 & 2014 & 2015 & 2016 & TOTAL & $\%$ \\
\hline Samples containing Cadmium & 0 & 0 & 65 & 4 & 93 & 34 & 114 & 60 & 61 & 431 & 60 \\
Samples without Cadmium & 23 & 115 & 15 & 2 & 72 & 6 & 8 & 31 & 17 & 289 & 40 \\
TOTAL & 23 & 115 & 80 & 6 & 165 & 40 & 122 & 91 & 78 & 720 & 100 \\
\hline
\end{tabular}

Table 5. Summary table of the samples analyzed as part of the official control of lead (2008-2016)

\begin{tabular}{llllllllllll}
\hline YEAR & 2008 & 2009 & 2010 & 2011 & 2012 & 2013 & 2014 & 2015 & 2016 & TOTAL & $\%$ \\
\hline Samples containing lead & 0 & 0 & 53 & 4 & 112 & 35 & 111 & 93 & 32 & 440 & 58 \\
Samples without lead & 23 & 115 & 15 & 2 & 53 & 5 & 12 & 43 & 47 & 315 & 42 \\
TOTAL & 23 & 115 & 68 & 6 & 165 & 40 & 123 & 136 & 79 & 755 & 100 \\
\hline
\end{tabular}

\section{Results}

The results shows, on the one hand, that Senegal's fishery products are not toxic (heavy metal content are below the limit value) and, on the other hand, that $64 \%$ of the samples of fishery products analyzed in the laboratory detect the presence at least one of the three heavy metals. However, this rate conceals enormous disparities. If the results are analyzed by contaminant, the mercury is detected on $71 \%$ of the samples against $60 \%$ for the cadmium and $58 \%$ for the lead. This would mean in other words that in fishery products exported from Senegal are much more contaminated by mercury and cadmium than by lead.

The results of the present study revealed that the mercury was the only contaminant detected in the samples in 2008 and 2009. The cadmium and lead content in the fish flesh was under the detection limit (see Figures 1,2 and 3) or they were not found in the fish analyzed regardless of the species.

The results also show that heavy metals are more concentrated in predatory and / or large migratory species (swordfish, tuna, marlin and shark) than in the intermediate species (sea bream, red mullet, sompatt, etc.). This heavy metals contamination is very low (at trace state) in broths and soles (Figures 3, 4 and 5). The greatest mercury contamination value $(0.55 \mathrm{ppm})$ was noted in the cuttlefish on all species during the nine years of study. 


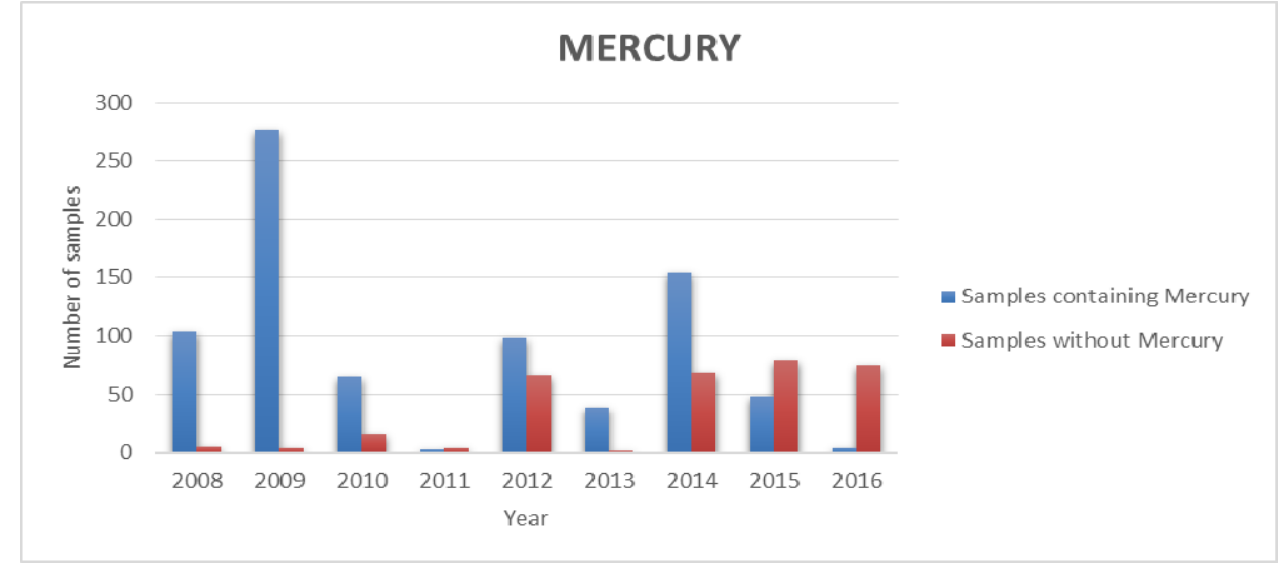

Figure 1. Distribution of analyzed samples according to their mercury contamination

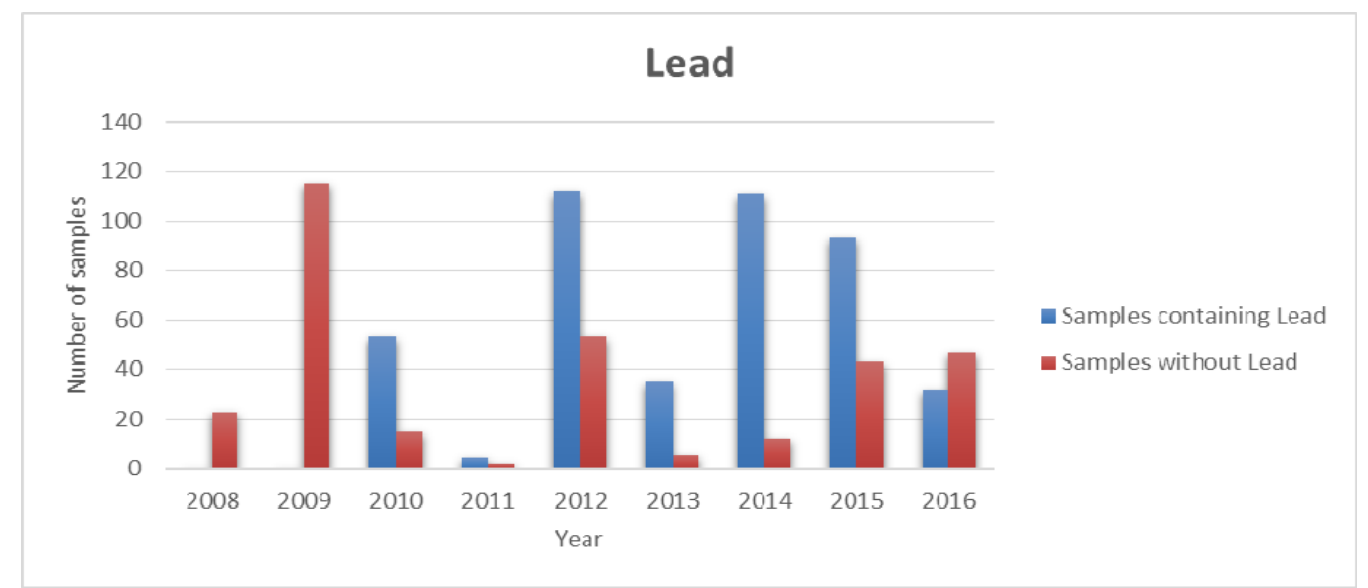

Figure 2. Distribution of analyzed samples according to their lead contamination

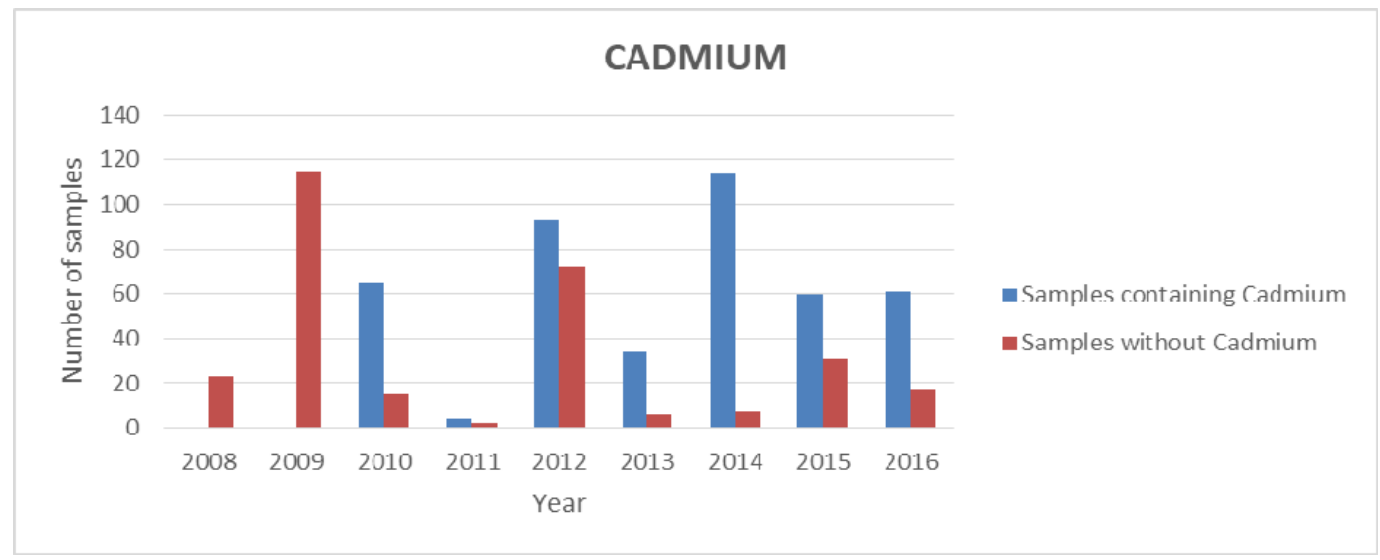

Figure 3. Distribution of analyzed samples according to their Cadmium contamination 


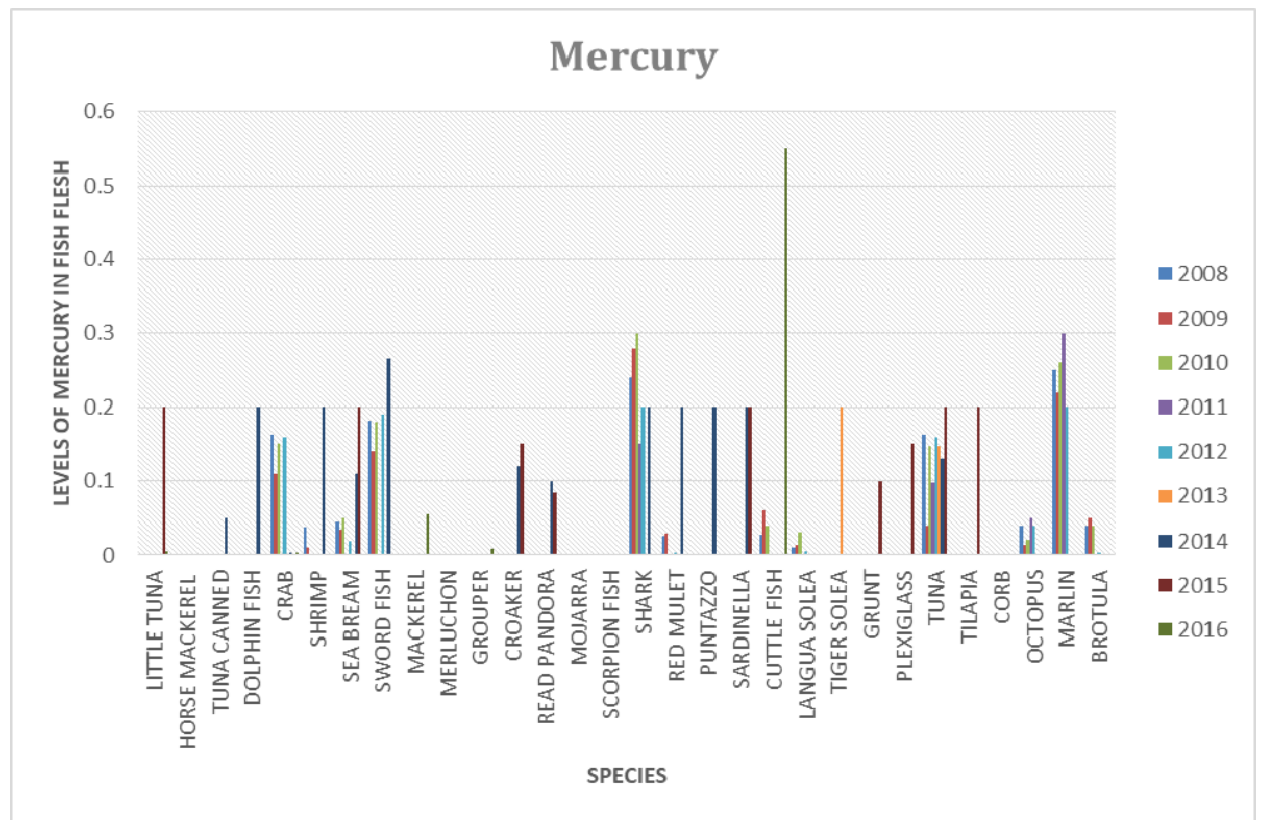

Figure 4. Evolution of the contamination level of mercury by species from 2008 to 2016

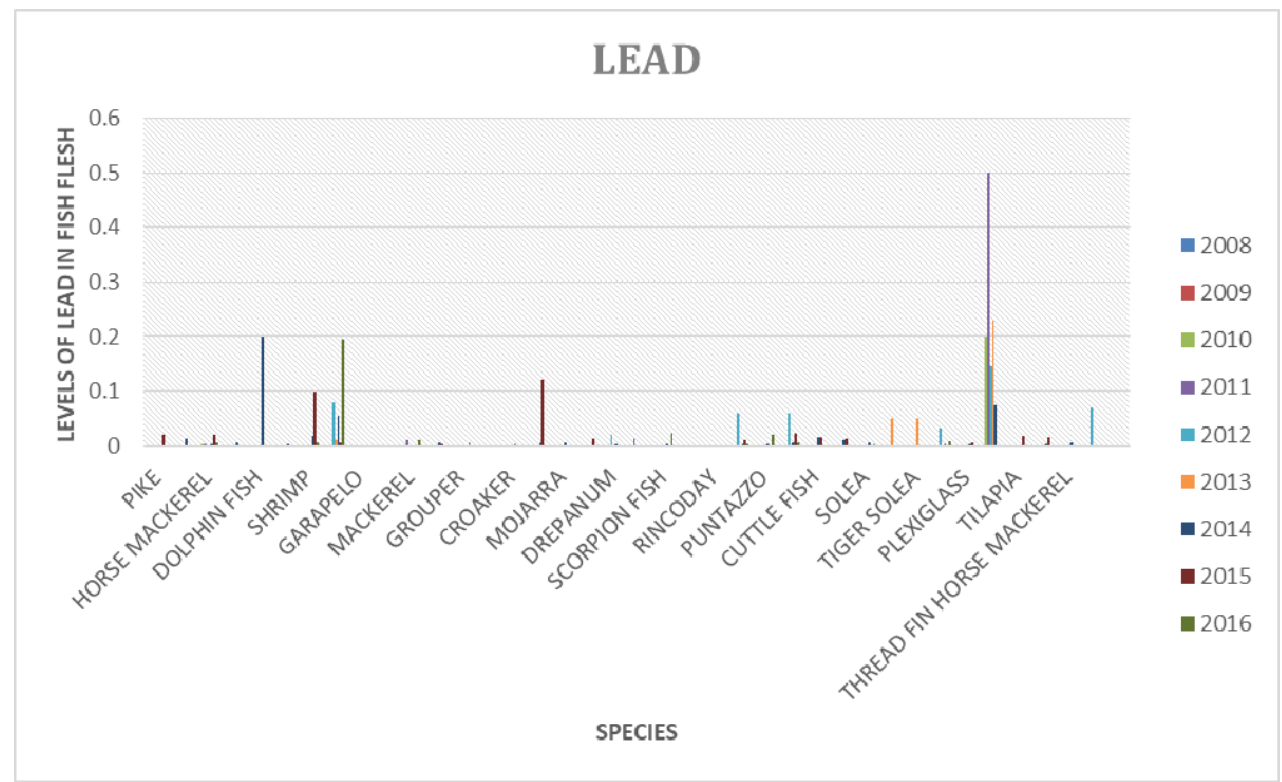

Figure 5. Evolution of the contamination level of lead by species from 2008 to 2016 


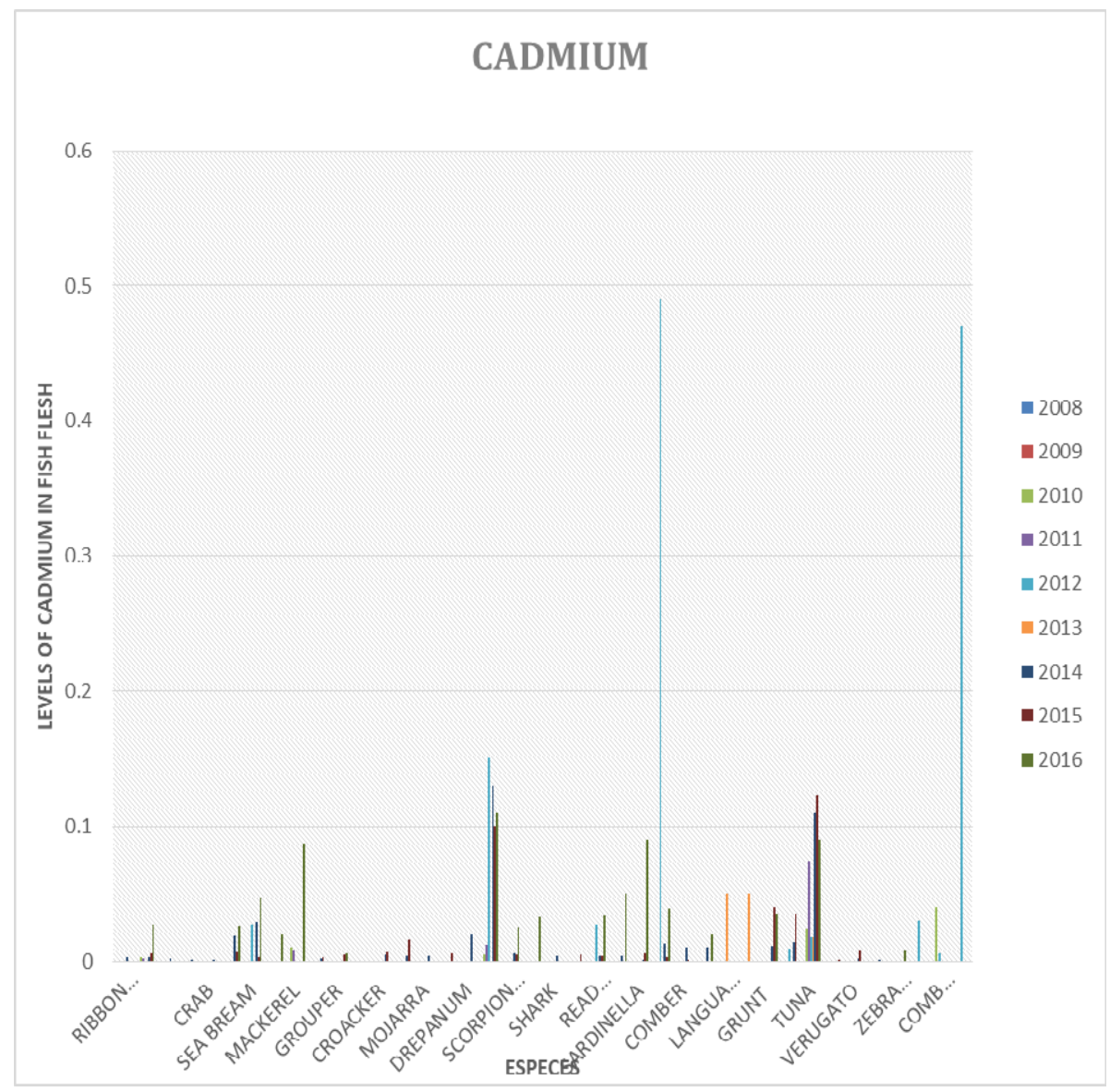

Figure 6. Evolution of the contamination level of Cadmium by species from 2008 to 2016

The distinction of the three groups (predatory and / or migratory species, intermediate species and invertebrates) according to their level of heavy metal contamination is much more visible with mercury. It does not appear in Figures 5 and 6 corresponding respectively to lead and cadmium because of the very high percentages of the results below the threshold of detection of these two metals $(0.005 \mathrm{mg} / \mathrm{kg}$ for cadmium and $11.2 \mu \mathrm{g} / \mathrm{kg}$ for lead $)$. However, tuna is everywhere distinguished and would be considered a species accumulating all three metals.

The results showed that for mercury, large predatory and / or migratory species are the most contaminated. These include marlin $(0.25 \mathrm{ppm})$, dolphinfish $(0.20 \mathrm{ppm})$, swordfish $(0.19 \mathrm{ppm})$ and tuna $(0.13 \mathrm{ppm})$. Beside this group, there are Sardinella, Tiger solea and Puntazoo with the mercury content of $0.2 \mathrm{ppm}$, the cuttlefish and Croaker with mercury contamination level of $0.13 \mathrm{ppm})$.

Regarding lead, the differentiation between species does not stand out so much at the level of the average rates obtained. Tuna has the highest rate $(0.22 \mathrm{ppm})$ followed by dolphinfish and red pandora $(0.20 \mathrm{ppm})$, finally seabream and shrimps $(0,11 \mathrm{ppm})$. With regard to cadmium, Cuttlefish (0.13 ppm) have the highest levels.

Comparing the overall averages of heavy metal concentrations across all species over the nine (9) years, we find that mercury has the highest average level $(0.09 \mathrm{ppm})$ followed by lead $(0.04 \mathrm{ppm})$ and finally the cadmium $(0.03 \mathrm{ppm})$. 


\section{Macrothink}

Journal of Food Studies

ISSN 2166-1073 2019, Vol. 8, No. 1

However, it should be noted that this average is only an indicator of the overall level of heavy metal contamination but does not make much sense as it can not be interpreted under the regulation. This interpretation is done by species or group of species in order to assess the levels of contamination of all species by heavy metals. This is to compare the results of heavy metals with the current regulations (the Senegalese decree $n^{\circ} 014352$ of September 28th, 2016 modifying the Decrees n ${ }^{\circ} 05868$ of April 07th, 2014 and 00494 of February 11th, 2005 and the CE Regulation $\mathrm{N}^{\circ} 1881 / 2006$ of December 19, 2006 modified by the EC Regulations $N^{\circ}$ 629/2008 and 420/2011). (See Table 6)

By comparing the results obtained with the limit values authorized by the regulations, we find that all the results are satisfactory. However, the average lead content $(0.23 \mathrm{ppm})$ in the tuna samples is not very far from the maximum allowed limit $(0.3 \mathrm{ppm})$.

Table 6._Appreciation of the results obtained according to the regulations in force

\begin{tabular}{|c|c|c|c|c|c|c|c|c|}
\hline \multirow[t]{2}{*}{ Especies } & \multicolumn{3}{|c|}{$\begin{array}{l}\text { Average content from } 2008 \text { to } \\
2016 \text { (in ppm) }\end{array}$} & \multicolumn{3}{|c|}{$\begin{array}{l}\text { Maximum content authorized by } \\
\text { Regulation } 1881 / 2006 \text { and Decree } \\
14352 / 2016 \text { (in ppm) }\end{array}$} & \multirow[t]{2}{*}{ Interpretation } & \\
\hline & Mercury & Cadmium & Lead & Mercury & Cadmium & Lead & & \\
\hline Tuna & 0.1356 & 0.0508 & 0.2296 & & 0.1 & & $\begin{array}{l}\text { Very close to the } \\
\text { permitted lead } \\
\text { content limit }\end{array}$ & \\
\hline Little Tuna & 0.1000 & 0.0000 & 0.0000 & & & & & \\
\hline Swordfish & 0.1914 & - & - & & 0.25 & & & \\
\hline Shark & 0.0040 & 0.0040 & - & 1.00 & & & & 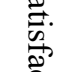 \\
\hline Marlin & 0.25 & - & - & & & & & $\stackrel{2}{2}$ \\
\hline Pike & 0.0000 & 0.0036 & 0.0000 & & 0.05 & & & 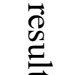 \\
\hline Dolphinfish & 0.2000 & 0.0010 & 0.2000 & & & & & $\stackrel{5}{\mathscr{b}}$ \\
\hline Seabream & 0.0762 & 0.0177 & 0.1150 & & & & & $\dot{0}$ \\
\hline Mackerel & 0.0277 & 0.02 & 0.0060 & & & & & $\vec{\sigma}$ \\
\hline $\begin{array}{c}\text { Horse } \\
\text { mackerel }\end{array}$ & 0.0001 & 0.0068 & 0.0057 & & 0.1 & & & 芯. \\
\hline Comb grouper & 0.017 & 0.0200 & - & & & 0.3 & & $\stackrel{\vec{O}}{\bar{O}}$ \\
\hline Plexiglass & 0.0760 & 0.0193 & 0.0037 & & & & & $\stackrel{2}{=}$ \\
\hline Red mullet & 0.0520 & 0.0115 & 0.0182 & & & & & 导. \\
\hline Grunt & 0.0504 & 0.0048 & 0.0105 & & & & & \\
\hline Drepanum & - & 0.0200 & 0.0020 & & & & & \\
\hline Sardinella & 0.2000 & 0.0323 & 0.0184 & & & & & \\
\hline Brotula & 0.0333 & 0.0100 & 0.0700 & & & & & \\
\hline
\end{tabular}




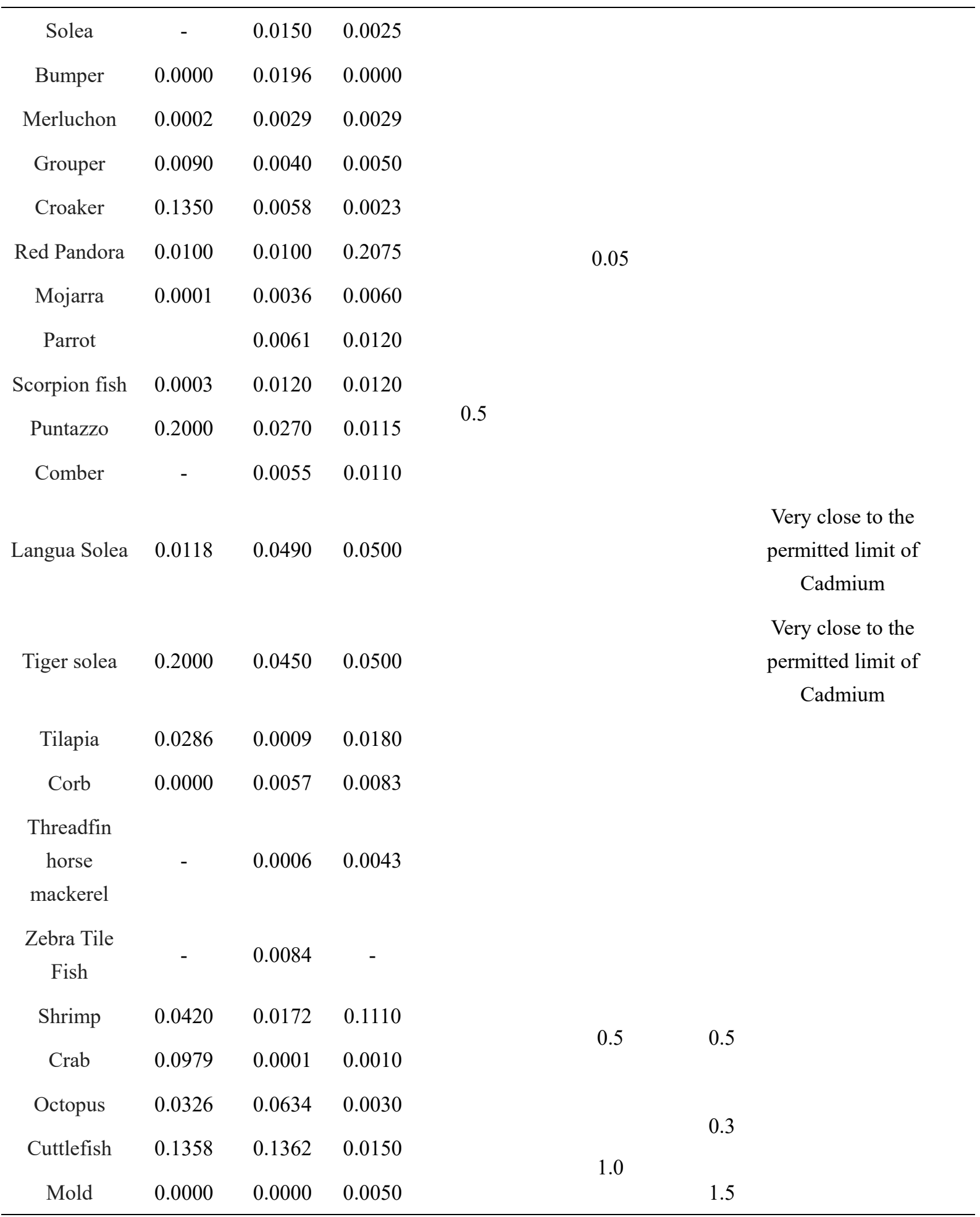

\section{Discussion}

The present study showed that large species are the most contaminated (marlin $(0.25 \mathrm{ppm})$, dolphinfish $(0.20 \mathrm{ppm})$, swordfish $(0.19 \mathrm{ppm})$ and tuna $(0.13 \mathrm{ppm})$ by mercury. These contamination levels of mercury are lower than those found by Voegborlo et al. (1999) that reported an estimated level of $0.66 \mathrm{ppm}$ of mercury was observed in Libya while the level was $3.07 \mathrm{ppm}$ of mercury observed in swordfish of USA, whereas the Food and Drug 


\section{Macrothink}

Administration (FDA) reported approximately $9.0 \mathrm{ppm}$ of mercury as a harmful level for human health (http://www.mercuryfacts.org).

The high contamination level of mercury in predators fish could be explained by the bioaccumulation and biomagnification of mercury. Because of their large size, marlins, swordfish, tuna and sharks have the ability to travel long distances and feed on what they find at their disposal. They are big predators that feed mainly on squid, crustaceans and other fish like sardinella, mackerel. The mercury provided by this food is one of the factors of increase of the content (Carey, 1981).

By their migratory these large species are exposed to polluted areas. Their exposures promote the increase of their mercury content. Mercury is a bioaccumulable metal. According to Picot, 2001 the greatest accumulation of mercury in tuna and swordfish can be explained by the affinity of the tissues of the latter to the methylmercuric cation $(\mathrm{CH} 3-\mathrm{Hg}+)$ corresponding to the organometallic form. Similarly, Castro-Gonzalez and Mendez-Armenta (2008) revealed that mercury is the one of the most toxic metals with tendency to bind to the sulfide group of proteins and deposits in muscles that can explain the highest concentration in large fish in the present study.

Longevity is another factor that promotes the accumulation of high levels of mercury in swordfish and tunas. The longer the service life, the higher the contents is. These above parameters are involved in bioaccumulation (Picot, 2001).

In addition to bioaccumulation discussed above, biomagnification leads to high levels of species at the top of the fish chain (tuna and swordfish). In fact, large species eat small species, thus accumulating the quantities of mercury ingested by them; hence increasing concentrations as the food chain move up or bottom up (Picot, 2001).

The highest cadmium level was found in Cuttlefish $(0.13 \mathrm{ppm})$ and was lower in fish. This phenomenon is explained by the fact that in the marine environment, bioconcentration factors (BCF) for cadmium are higher in invertebrates (primary producers) than in fish (INERIS, 2005). The contamination levels of cadmium in Cuttlefish $(0.13 \mathrm{ppm})$ analyzed in this study are lower than reported values of cadmium $0.23 \mathrm{ppm}$ in the USA (Gale et al. 2004). Contrary, the highest cadmium level found in Cuttlefish $(0.13 \mathrm{ppm})$ in this study was also higher than the level of cadmium 0.01 ppm observed in Egypt.

The high content of the cadmium content in Cutlefish can be explained by the fact that the latter feed on small molluscs, crabs, shrimp, fish, octopus, worms, and other cuttlefish and retain in their digestive system the cadmium contained in these animals.

In seawater, almost all cadmium is found as cadmium chloride. Among the fish, tunas are those with a somewhat high level of cadmium contamination $(0.05 \mathrm{ppm})$, which can be explained by their high mobility and predatory nature. These are the two (02) factors that favor its exposure.

Tuna has the highest lead contamination rate $(0.22 \mathrm{ppm})$ followed by dolphinfish and red pandora $(0.20 \mathrm{ppm})$, finally seabream and shrimps $(0,11 \mathrm{ppm})$. In regards to these results, the lead levels are below the maximum permitted concentrations authorized by Senegalese Regulation 1881/2006 and Decree 14352/2016, Commission of the European Communities (EC) 2006 and Turkish Food Codex (TFC) 2009. 


\section{Ml Macrothink}

The fact that all the results are satisfactory in view of national and European regulations could be explained by the fact that the species analyzed being marine species have not yet reached a level of contamination that is too high. Senegal, belonging to the FAO 34 zone, has not yet reached a level of contaminant release that could be alarming like the industrialized countries. However, such a study could provide very different results if the species came from inland fisheries.

\section{Conclusion}

This study was performed to evaluate the heavy metals contamination level in fish and shellfish products exported from Senegal. The results of the study revealed that heavy metals (mercury, cadmium, lead) in fish products exported from Senegal are below the maximum permitted concentrations authorized by Senegalese Regulation. Nevertheless, a chemical contaminants monitoring plan must be put in place for the official control of predatory and migratory species (tuna, swordfish, shark, marlin, etc.), which are starting to record somewhat high rates approaching reference.

For a better assessment of the contamination levels of heavy metals in fisheries products, a study commissioned by the fishery authorities should be taken in the three main senegalese fishing zones (north zone, central zone, and south zone) with a monthly sampling of species studied for 12 months to minimize bias. This study should be extended to inland fisheries products which due to their living environment are much more exposed to pollution problems. It would be also essential to extend at sub-regional level to define common plans solve the problem of chemical contaminants in fisheries products.

\section{References}

Altindag, A., \& Yigit, S. (2005). Assessment of heavy metal concentrations in the food web of lake Beysehir, Turkey. Chemosphere, 552-555. https://doi.org/10.1016/j.chemosphere. 2005.01.009

Carey, F. G., \& Robison, B. H. (1981). Daily patterns in the activities of swordfish Xiphias gladius observed by acoustic telemetry. Fishery Bulletin, 79(2), 277-292.

Castro-González, M. I., \& Méndez-Armenta, M. (2008). Heavy metals: Implications associated to fish consumption. Environmental Toxicology and Pharmacology, 26, 263-271. https://doi.org/10.1016/j.etap.2008.06.001

Chen, C. Y., Stemberger, R. S., Klaue, B., Blum, J. D., Pick- hardt, C., \& Folt, C. L. (2000). Accumulation of heavy metals in food web components across a gradient of lakes. Limnol. Oceanogr., 45, 1525-1536. https://doi.org/10.4319/1o.2000.45.7.1525

EC (COMMISSION REGULATION). (2006). Setting maximum levels for certain contaminants in foodstuffs, No 1881/2006 of 19 December 2006.

Förstner, U., \& Wittman, G. T. W. (1983). Metals pollution in the aquatic environments (p. 486). Berlin: Springer.

Gale, N., Adams, C., Wixson, B., Loftin, K., \& Huang, Y. W. (2004). Lead, zinc, copper, and cadmium in fish and sediments from the big river and flat river creek of Missouri's old lead belt. Environmental Geochemistry and Health, 26(1), 37-49. https://doi.org/10.1023/B:EGAH. 0000020935.89794.57 


\section{Macrothink}

Harte, J., Holdren, C., Schneider, R., \& Shirley, C. (1991). Toxics A to Z, A Guide to Everyday Pollution Hazards (p. 478). University of California Press, Oxford, England.

INERIS. (2005). Le Cadmium et ses dérives, Fiches de données toxicologiques et environnementales des substances chimiques, $60 \mathrm{p}$.

Kalay, M., \& Canli, M. (2000). Elimination of essential ( $\mathrm{Cu}$ and $\mathrm{Zn})$ and non-essential (Cd and $\mathrm{Pb}$ ) metals from tis- sue of a freshwater fish, Tilapia zilli. Tr. J. Zool., 24, 429- 436.

Picot, A. (2001). Les effets des métaux lourds sur l'environnement et la santé, rapport $n^{\circ}$ 2979. Assemblée nationale, rapport $n^{\circ} 261$ du Sénat

Rashed, M. N. (2001). Monitoring of environmental heavy met- als in fish from Nasser Lake. Environ. Int., 27, 27-33. https://doi.org/10.1016/S0160-4120(01)00050-2

Unlu, E., \& Gümgüm, B. (1993). Concentrations of copper and zinc in fish and sediments from the Tigris river in Turkey. Chemosphere, 26, 2055-206. https://doi.org/10.1016/0045 $-6535(93) 90031-Y$

Veena, B., Radhakrishnan, C. K., \& Chacko, J. (1997). Heavy metal induced biochemical effects in an estuarine teleost. Indian J. Marine Sci., 26, 74-78

Asonye, C. C., Okoline, N. P., Okenwa, E. E., \& Iwuanyanwu, U. G. (2007). Some physicochemic characteristics and heavy metal profiles of Nigerian rivers, streams and waterways. African Journal of Biotechnology, 6, 617-624.

Chale, F. M. M. (2002). Trace metal concentrations in water, sediments and fish tissue from Lake Tanganyika, Tanzania. The Science of the Total Environment, 299, 115-121. https://doi.org/10.1016/S0048-9697(02)00252-8

Gigon, P. L, (1975). Botransformation and biliary excretion of imipramine in rats under various experimental conditions. Arch. Int. Pharmacodyn, 216, 315-327

Okwonko, J. O., \& Mothiba, M. (2005). Physico- chemical characteristics and pollution levels of heavy metals in the rivers in Thohoyandou, South Africa. Journal of Hydrology, 308, 122-127. https://doi.org/10.1016/j.jhydrol.2004.10.025

Schüürmann, G., \& Markert, B. (1998). Ecological Fundamentals, Chemical Exposure and Biological Effects. In Ecotoxicology. John Wiley \& Sons, Inc. and Spectrum Akademischer Verlag.

TFC. (2009). Official Gazette of Republic of Turkey. Notifications changes to the maximum levels for certain contaminants in foodstuffs (in Turkish). (Notification No: 2009/22), Issue: 27143.

Ubillús, F., Alegría, A., Barberá, R., Farré, R., \& Lagarda, M. J. (2000). Methylmercury and inorganic mercury determination in fisf by cold vapour generation atomic absorption spectrometry. Food Chemistry, 71, 529-533

Voegborlo, R. B., El-Methnani, A. M., \& Abedin, M. Z. (1999). Mercury, cadmium and lead content of canned tuna fish. Food Chemistry, 67(4), 341-345. https://doi.org/10.1016/S0308 $-8146(98) 00008-9$ 


\section{Macrothink}

\section{Copyright Disclaimer}

Copyright for this article is retained by the author(s), with first publication rights granted to the journal.

This is an open-access article distributed under the terms and conditions of the Creative Commons Attribution license (http://creativecommons.org/licenses/by/3.0/). 